\title{
Factors Affecting New Graduate Entrepreneurial Intention: An Empirical Study of the Unemployed Graduates in Nigeria
}

\author{
Wisdom Kalabeke \\ Limkokwing University of Creative Technology,Malaysia \\ Email: kalabeki.wisdom@gmail.com
}

http://dx.doi.org/10.18415/ijmmu.v5i2.342

\begin{abstract}
The current research examined the effect of Startup capital, Educational system and Culture on entrepreneurial intention among fresh graduate in Nigeria. The data were collected from Graduates and undergraduate's students in the University of Lagos, Kaduna State University, Abia State University, University of Calabar and Niger Delta University, 250 questionnaires were distributed and 180 responses were collected and analyzed. The findings confirmed the strong positive relationship between variables of the study. Startup Capital/Infrastructure, Education and Cultural Factor account for 58\% of the variance in Entrepreneurial intention. The study hopes to help academicians and curriculum planners to be mindful of entrepreneurship when drafting and implementing curriculum to motivate student accumulate intentions to start a business.
\end{abstract}

Keywords: Entrepreneurship Intention; Startup Capital; Education; Cultural Values; Nigeria

\section{Introduction}

Entrepreneurs are the builders of an economy by identifying societal needs, strategically taking creative and innovative steps to supply those needs with the aim of making profit. When individual embrace an opportunity to create something successfully, they become independent and employers of labor, consequently, reducing unemployment rate and perhaps the dependents of the employee's economic situation improves which in return creates harmony and economic growth in the society (Shepherd., H. \& Patzelt., 2017). The entrepreneur's contributions to society are immeasurable due to the decreasing of the unemployment rate (Shrm., 2017). Many nations have identified the importance of entrepreneurship as the economy been run by entrepreneurial activities, therefore, several measures have been designed to foster and promoting entrepreneurship by many governments as well as educational institutions voracious researches on this line of specialization recognizing the importance of entrepreneurship. Nigeria is the most populous nation in Africa with approximately 180 million people ranked as 7th most populous nation in the world with an ever-increasing unemployment rate of 3.50 million to 11.550 million between 2009 to 2017 (Trading Economics., 2017), This unemployment rate is higher for persons between the age of 15-24 approximately $25.2 \%$. between the age of 15-24 are Secondary School and University graduates which are mostly unemployed. There are several reasons for the unemployment rate and one of the most important reason is the higher fraction of the population 
(Youths) are not involved in entrepreneurship, (Nwogwugwu \& Irechuku., 2015), however, this study tried to find factors to encourages the fresh graduates to be entrepreneurial minded and taking action.

\section{Research Problem}

Nigeria population amount to 180 million people ranked 7th most populous nation in the world with an ever-increasing unemployment rate of 3.50 million to 11.550 million between 2009 to 2017 (Trading Economics 2017), This unemployment rate is higher for persons between the age of 15-24 approximately $25.2 \%$ of the population are university graduates. Skepticism arose why these graduates do not have intention to start a business to be self-reliant consequently creating employment for others reducing the level of unemployment among youth, generally promote economic growth. The result of the research tries to help undergraduates and graduates in Nigeria to be self-reliant after studies, early planning and personal saving is required since it is cumbersome to get funded. It also contributes to the educational sector, the need for entrepreneurial training concentration on the curriculum of schools to produce young graduates with the capabilities to create and innovate to be self-employed. As a platform of understanding to the various ethnic groups in Nigeria to reflect on the importance of entrepreneurship and the contribution of culture to that effect. Finally, serves as reference in the academic field for further research and knowledge of the level of the entrepreneurial initiative level of young graduate as the basis of unemployment.

\section{Literature Review Entrepreneurial Intention}

Wu, Wu., 2008; Nabi, et al., 2006 and Guerrero, et al., 2008 defined entrepreneurial intention as a state of mind that people wish to create a new business or a new value driver inside an existing one. Entrepreneurship intention is also defined as the increasing conscious condition of the mind that a person desires to start a new enterprise or create new organization (Khuong \& Nguyen., 2016; Doug Scott $., 1999)$.

Every behavior and action is born of intention (Farruk., 2017). The intention to start a business is born by the cognitive affirmation of the will of a person to exercise a giving behavior. Behavior is controlled by several factors either culture, education, status, prestige etc., According to Fayola and Gaily (2009) the behavioral intention, is explained in a theory used in the sciences of the behavior, which is the result of three abstract precursor, firstly, Attitudes to the behavior make up the first precursor or antecedent. "The intention to create a company is a function of the degree of favorable or unfavorable evaluation of the behavior in question".

Entrepreneurial intention can be best explained with the Theory of Planned Behavior (TPB) model propounded by Ajzen's (1991) TPB and Shapero's (1982) model of the entrepreneurial event (Karali., 2013). This model is of the opinion that humans are rational in the choices they make, based on this rationality the intentions of an individual may be restricted to certain behavior, rational business intentions are likely to appreciate than absurdity. Lack of employment make citizens go creative and innovate to be self-reliant but opposite the case in Nigeria, the lack of employment commutes some individuals to commit crimes Jeddah (2016). Entrepreneurship is the most effective way that will uplift the problem of unemployment in Nigeria (European Commission., 2003).

Ofili (2014) also affirm that "entrepreneurship is critical to the development of societies" therefore youths should imbibe the intention to start a business, entrepreneurial intention is the intention to start a new business (Pillis \& Reardon., 2007). Wu, Wu, 2008; Nabi, et al., 2006; Guerrero, et al., 2008 
define entrepreneurial intention as a state of mind that people wish to create a new business or a new value driver inside an existing one. Ihugba, Odii \& Njoku (2012) study confirm that the entrepreneurial development agencies exist in theory but practically lifeless because the desired result is not achieved due to poor implementation.

\section{Startup Capital and Entrepreneurial Intention}

The importance of financial capital to young entrepreneurs cannot be overemphasized, (Straub., 2012) it is one of the most important resources needed to implement the business idea, many visions are collapsing due to financial incapacitation as new graduates who have been in school for their entire age with no adequate finance, no asset, no managerial capabilities and inexperience, just a solid business idea suffers financial constraint. According to Simon \& Aja (2013)" lack of startup capital and poor access to formal credit facilities are the main constraints to entrepreneurship" New graduates encounter financial constraint for lack of adequate and transparent credit system.

Previous researches shows that young people are more entrepreneurial minded "More than 29 million adults from 18 years were starting or running new businesses in 2011" (Babson College., 2013), mostly fresh graduate in Nigeria who has been job hunting for five to seven years after graduating from the university are willing to start up a business, most graduate have a sound business proposals and ideas, what bereft off from implementing the project is finance or startup capital. Engelschiøn (2014) findings shows that young people faces financial capital constraint mostly which lead to their non-business startup consequently, not enough time to build up capital needed, Omeh (2016) also stated that Microfinance banks are initiated to give out loans to retailers and small entrepreneurs to do this they have to secure a loan from the central bank first (CBN 2004). Young entrepreneurs getting a loan to start a business is a tedious process because most youth lack asset as collateral for loan. According to Samsom, Olubunmi and Olusegun (2013) most of the loan criteria sets by banks are hardly fulfilled by young entrepreneurs, Epke., Mat \& Razat (2010).

In the research of Fasehun \& Bawayo (2014) assume that despite the heavy borrowing and lending process banks only lend when they suspect government safety net to mitigate any potential loss, Omeh, (2016), Nwuzoh, 2016 supported this fact. In the youth business international article (2010) identify the rigidity of commercial banks giving loan to young entrepreneurs and implore to identify the financial helplessness of young entrepreneurs.

Startup capital is important in relation to infrastructure, CRC Research (2012) conceptualize infrastructure as "the set of structural elements that supports the day to day function and influences the direction of human society".

According to Delmon in world bank (2006) "Poor infrastructure impedes a nation's economic growth and international competitiveness.

\section{Education System and Graduate Entrepreneurial Intention}

Education is an important aspect of human capacity development it plays a significant role in inculcating entrepreneurial skills from one person to another through direct and indirect learning process, therefore the right type of education is needed at various level of education (UNICEF., 2000). Hence, the educational system of a country is fundamental in instilling entrepreneurial values. 
Yero (2002) define education as to developing the knowledge or skills of student. Education is the process of transmitting/ acquiring relevant knowledge, developing skills and attitudes of human that unleash capabilities of leading and cognizance Küttim et al., (2013). Education make people to think voraciously and refining innate qualities, identifying this, a system of education should include direct entrepreneurial courses that trigger individuals to have business intentions after graduation. The purpose of education is outwardly misinterpreted in many universities in Nigeria, Education has been acclaimed to be the channel that convey human for a gainful employment (Osinubi., 2006). Halliru (2016) argued that, to instill entrepreneurial intention in the minds of the youth should begin as early as from the elementary school level to the middle school level as they are young there is curiosity and high propensity to be skillful, prudence, astute language efficiency and effectiveness yield entrepreneurial mindset. Marques \& Albuquerque, (2012), argued that acquiring the rightful education may stimulate entrepreneurial intention of a person (Garavan \& O'Cinneide., 1994) extant researches shows that university student studying business and its related courses are more likely to have business inclination.

\section{Cultural and Entrepreneurship Intention}

Tukur (1931) etymologically explained culture from its latin word Colere which means "till, tend to cultivate" etc. Through the extensive study of human society, kroner and parson (1958) conceptualize culture as the "transmitted and created content and patterns of values, ideas, and other symbolicmeaningful systems as factors in the shaping of human behavior" (Alvarez \& Urbano 2012). And similar concepts by Hawkins et., al (2004), PATEL (2012), Brown (1991) and Hofstede (1980). Researcher perceive culture as the pattern of living for a giving group of individuals distinct from other groups exhibited and maintained from generation.

Culture can play a significant role on the basis of intention, location, language, values, beliefs and aspirations. "It is also the vector that orients and gives meaning to all existence and all practice" (Tshikuku., 2001). The culture of Nigeria is broad (Rakov., 1990) and within Nigeria there are several hundreds of cultures each possess a separate belief about starting up a business. In Nigeria some cultures promote a strong business intention while others do not. The major ethnic groups and culture includes, the Hausa's, Yoruba, Igbo and the Izon, these four ethnic groups exhibit different cultures and the various cultures affects their business intentions positively and negatively as the case may be (Cyperi., 2017). The Hausa's believe that for you to be successful in business is not through hard work but by divine enablement and destiny, this cultural believe is a factor that is responsible for the poor development of entrepreneurship among the Muslims, Haliru (2011). The Northern culture does not promote independent therefore youths lacks the initiative to start a business. Yakubo (2005) sited in the research of Haliru (2011) "Zafin nema baya kawo samu" which is interpreted as the "intensity to search does not bring earning”. (Zakaria., 1969; Kaushal., 1977).

Igbo culture promotes independency of servant (apprentice) are encouraged the situation whereby apprentice serve under master for a stipulated time period when elapsed the master will set up a business branch for the apprentice to be independent on his own. Craigen (2017) the vigor for self-help compel them to be creative and innovative, this led the Igbo ethnic group to be the most successful business group of people in Nigeria. Another cultural factor responsible for the business success of the Ndigbos are the language and use of proverbs, most Igbo proverbs are spirited and advocate for entrepreneurship instill on the young minds (Ogochukwu., 2016; Nafukho., 1998; Mamuzo., 2012). 


\section{Objectives of the Study}

This research alludes to find out factors underpinning fresh graduate non- entrepreneurship involvement in Nigeria, the specific objectives are;

i. To asses Startup Capital (Finance) and infrastructural factors responsible for graduates not setting up a business.

ii. Determine the Educational causes of lack of entrepreneurship among the youths

iii. Identify the level of graduate entrepreneurial intention base on culture.
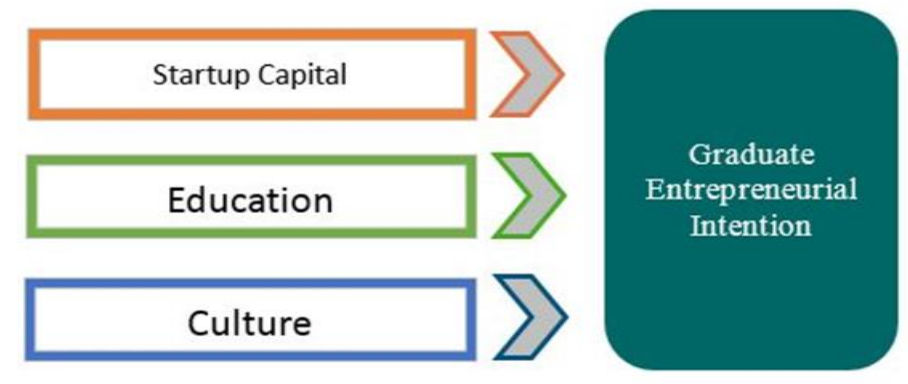

Fig. 1 Frame Work of the Study

\section{Research Hypothesis}

H1, there is a significant relationship between Startup capital and new graduate entrepreneurial intention.

$\mathrm{H} 2$, The Education system affects graduate entrepreneurial intention

$\mathrm{H} 3$, Culture plays a Consequential role in entrepreneurial intention

\section{Methodology}

Quantitative approach which is according to Johannesen, Tufte \& Christoffersen (2010) best fitted to investigate the nature of human actions was applied in this study. This method changes nonnumeric into numeric data therefore allows the researcher to analyze the data through statistical instrument by using SPSS software. The population of the research is the yearly estimated number of graduates in Nigeria from various universities amounting to 500,000 (Esiri., 2016), "Student samples are very common in entrepreneurship research" (LIÑÁN; CHEN., 2009) "especially given evidence that university graduates between 25 and 34 years of age show the highest propensity toward starting up a business" (Reynolds; Bygrave; Autio., 2004). A total of 184 respondents were used for the analysis comprising of $70 \%$ Unemployed graduates and $30 \%$ of final year students across Nigerian Universities. In the first part, the multiple-choice questionnaires were designed to collect the demographic information of the respondents. The second part of the questions is the viewpoint of the respondents on entrepreneurship intention and its affecting factors. "All measures were collected based on a five point Likert scale" in which " 1 " represents "strongly disagree" and " 5 " is "strongly agree" Chen (2009), The data in the survey were collected from Graduates and undergraduates in the University of Lagos, Kaduna State University, 
Abia State University, University of Calabar and Niger Delta University, 250 questionnaires were distributed and 184 responses were collected and analyzed.

\section{Demographic Profile of Respondents}

The sum of all participants in survey amounted to 184 as shown in the subsequent frequency tables, of which, 105 representing $57.1 \% \%$ of males, while $76(42.9 \%)$ represents the female gender. The age bracket of participant were 31 to 40 amount to $47.3 \%$ the highest representation in the study, followed by those within the age of 20 to 30 represent $37.5 \%$ and below 20 years 10.9 finally $41-50$ equally to $4.3 \%$ only which was the lowest representation. 147 (79.9\%) out of the 184 were single only $37(20.1 \%)$ are married which is a good representation as most young graduates are not married. 90 participants (48.9\%) were delineated from the Jaw ethnic group while 31 (16.8\%) and 30 (16.3\%) were from the Hausa and Igbo ethnic groups respectively, followed by Yoruba ethnic group of $29(15.8 \%)$ and others $2.2 \%$. More than half of the participants $125(67.9 \%)$ were graduate which is a good data collected as our target audience and 28 (15.2) Diploma 13.6\% and 3.3\% are master and PhD holders respectively.

\section{Results and Discussion}

The variables on the analysis showed the high level of internal consistency, Cronbach's alpha more than 0.7 and analysis confirmed the research variables and dependent variable to have a strong positive relationship. Startup Capital/Infrastructure, Education and Cultural Factor account for $60 \%$ of the variance in Entrepreneurial intention, this measures the amount of variance in the dependent variable that the research variables account for when taken as a group. The findings further shows cultural values as the most closely positively related to Entrepreneurial intention (EI) of students and Fresh graduates, Followed by star-up capital and Educational System positively linked with entrepreneurial intention. To reconfirm this finding, Ajzens theory of planned behavior was used to explain the intention, to start a business, is a process of planning and the planning process involve an intentional behavior (Krueger Jr et al., 2000).

Table 1 Coefficient (test each variable at Alpha =.05)

\begin{tabular}{|c|c|c|c|c|c|c|c|}
\hline \multirow[t]{2}{*}{ Model } & \multicolumn{2}{|c|}{$\begin{array}{l}\text { Unstandardized } \\
\text { Coefficients }\end{array}$} & \multirow{2}{*}{$\begin{array}{l}\text { Standa } \\
\text { rdized } \\
\text { Coef. }\end{array}$} & \multirow[t]{2}{*}{$\mathrm{t}$} & \multirow[t]{2}{*}{ Sig. } & \multicolumn{2}{|c|}{$\begin{array}{l}95.0 \% \text { Confidence } \\
\text { Interval for B }\end{array}$} \\
\hline & B & $\begin{array}{l}\text { Std. } \\
\text { Error }\end{array}$ & & & & $\begin{array}{l}\text { Lower } \\
\text { Bound }\end{array}$ & $\begin{array}{l}\text { Upper } \\
\text { Bound }\end{array}$ \\
\hline (Constant) & -5.520 & 1.054 & & -5.238 & .000 & -7.600 & -3.441 \\
\hline St.Capital_Infr & .190 & .065 & .237 & 2.943 & .004 & .063 & .318 \\
\hline Edu_Syst & .139 & .058 & .164 & 2.404 & .017 & .025 & .254 \\
\hline Culture_Fact & .413 & .087 & .430 & 4.731 & .000 & .241 & .585 \\
\hline
\end{tabular}


In the Coefficient Table 1, Capital and Infrastructural variable is $0.004 \mathrm{sig}$, which is much less than 0.05 Alpha value, therefore startup capital and Infrastructure are significant predictors of entrepreneurial intention. Looking at the Educational fact it is also a significant predictor of entrepreneurial intention since its sig $<0.05$ which is 0.017 as well as Culture is a significant determinant of entrepreneurship with 0.000004 .

Table 2 Correlations

\begin{tabular}{|c|c|c|c|c|c|}
\hline & & $\begin{array}{l}\text { Str.Capital } \\
\text { _Inf }\end{array}$ & Edu_sys & Culture & EI \\
\hline \multirow{3}{*}{ Str.Capital_Inf } & Pearson Correlation & 1 & $.595^{* *}$ & $.798^{* *}$ & $.678^{* *}$ \\
\hline & Sig. (2-tailed) & & .000 & .000 & .000 \\
\hline & $\mathrm{N}$ & 184 & 184 & 184 & 184 \\
\hline \multirow{3}{*}{ Edu_Sys } & Pearson Correlation & $.595^{* *}$ & 1 & $.701^{* *}$ & $.607^{* *}$ \\
\hline & Sia (2-tailed) & 000 & & 000 & 000 \\
\hline & $\mathrm{N}$ & 184 & 184 & 184 & 184 \\
\hline \multirow{3}{*}{ Culture } & Pearson Correlation & $.798^{* * *}$ & $.701^{* *}$ & 1 & $.735^{* *}$ \\
\hline & Sig. (2-tailed) & .000 & .000 & & .000 \\
\hline & $\mathrm{N}$ & 184 & 184 & 184 & 184 \\
\hline \multirow{3}{*}{ EI } & Pearson Correlation & $.678^{* *}$ & $.607^{* *}$ & $.735^{* *}$ & 1 \\
\hline & Sig. (2-tailed) & .000 & .000 & .000 & \\
\hline & $\mathrm{N}$ & 184 & 184 & 184 & 184 \\
\hline
\end{tabular}

**. Correlation is significant at the 0.01 level (2-tailed).

Therefore, the three predictor variables are statistically significant which means they account for a unique amount of variance in entrepreneurship intention most especially culture and startup capital.

Person correlation was conducted to examine the relationship between Entrepreneurship intention, Startup capital/ infrastructure, Education and Culture. Entrepreneurship intention was more closely positively related to culture, $\mathrm{r}(198)=.798 \mathrm{P}>.001$, followed by Financial capital and infrastructure, $r(198)=.678, p>.001$ than to educational factor, $r(198)=.595, \mathrm{p}>.001$. These findings indicate that culture explains more of variability in entrepreneurship intention as well as Financial capital 
and infrastructure than Education does. Effective size of culture $(\mathrm{r} 2=.58)$ indicate that cultural values and aspirations towards entrepreneurship of an ethnic group account for a large portion (58\%) of the variability in entrepreneurship intention.

\section{Limitations and Future Suggestion}

There was some restriction in the research process. For instance, time limitation, although the purpose of the research is reached but the time frame used for the entire research was limited to 12 weeks which is limited to verify changes of information and behavior of respondent, the scope of discussion is limited base on the limited experience of the researcher, the areas discussed were not in-depth compare to the works of well experienced researcher. Furthermore, there are several factors ranging from social, personal and economic factors affecting entrepreneurial intention deduced from other research but the research focused only on Startup capital/ infrastructure, Education and cultural factors other important factors such as motivation, family background and etc., were not mentioned for narrowing down the findings to three factors. Subsequent research will consider such other important factors affecting business orientation of the young graduate in Nigeria and the cultural factor were the Igbo women are not much involved in business like the male counterparts.

\section{Conclusion}

The main purpose of this study was to find out if lack of finance access could have effect on entrepreneurship level for new graduates in Nigeria, Education and Culture could affect the level of entrepreneurship. The study used a quantitative approach and collection of data was done in Nigeria and research variables showing positive relationship with EI as well the theory of planned behavior was ascertained to support findings. Furthermore, there is need for government to reduce the barriers associated with young graduate going into business as well as loosening the requirement for young graduated to have financial access to start a business and government provision for reasonable capital for micro-finance banks and system to closely watch its operation. Furthermore policy should be made to raise the awareness level of the citizens on the various programmed instituted to stimulate and encourage entrepreneurship between different cultures in the country. Promoting entrepreneurial education direct teaching in universities and other tertiary institutions as well as its inclusion into school curriculum is required. Special funds should be provided and focused on the graduate as they finish up the National Youth service those with business ideas can be funded (Ofili., 2014).

\section{References}

Afolayan, A. A. (2008). Country Paper: Nigeria Dynamics of International Migration in Nigeria.

Ajzen, I. (1991): “The theory of planned behavior", Organizational Behavior and Human Decision Processes, 50: 179-211.

Ajzen, I. (2001)'. “Nature and operation of attitudes”, Annual Review of Psychology, 52: 27-58.

Central bank of Nigeria. (2004). Microfinance Policy, Regulatory and Supervisory Framework for nigeria, p 6-8.

Drucker, P.F. (2007). Innovation and Entrepreneurship: Practice and Principles, Elsevier Ltd. 
Engelschiøn, A.-S. (2014). Master in change management Does increased access to finance enhance entrepreneurial activity among students?. Entrepreneurship, Management and Sustainable Development, https://doi.org/10.1108/WJEMSD-03-2017-0018.

Farruk et' al. (2017). Entrepreneurial Intentions: the Role of Familial Factors, Personality Traits and SelfEfficacy World Journal.

Fasehun, o. O. (2014). Technical Manpower and Entrepreneurship in a Developing Economy. Technology Education Journal. 9(1): 34-36.

Fayolle, A. \& Gailly, B., "Using the Theory of Planned Behavior to Assess.

Forlani, D. \& John, M.W. (2000). "Perceived Risks and Choices in Entrepreneurs' New Venture decisions", Journal of Business Venturing, 15(4): 305-322.

Halliru. (2016). The Effect of Culture on the Development of Entrepreneurs Among the Hausa Ethnic Group in Northern Nigeria, Journal of Marketing and Management, 4(1): 59-73 67.

Hawkins et., al. (1993); (2004). "New business entrepreneurship in the Japanese economy". Journal of Business Venturing, 8(2), 137-150.

Hofstede, Geert. (1980). Culture's consequences: International Differences in Work-Related Values. Beverly Hills, CA: Sage Publications.

Ihugba, O. A., Odii, A., \& Njoku, A. O. (2014). "Theoretical analysis of entrepreneurship challenges and prospects in Nigeria". International Letters of Social and Humanistic Sciences, 16(21): 21-34. Retrieved from http://www.scipress.com/ILSHS.16 Journal, 21: 997-1016.

Khuong \& Nguyen, (2016). "The Impact of Government Subsidies on Enterprises' R\&D Investment: A Panel Data Study”. Energy Policy, 89: 106-113.

Krueger, N.F. (1993). "The Impact of Prior Entrepreneurial Exposure on Perceptions of New Venture Feasibility and Desirability”, Entrepreneurship Theory and Practice, 18(1): 5-21.

Küttim et al. (2013). Entrpereneurship Education at the University Level and Student Entrepreneurial Intentions, Procedia-Social and Behavioral Sciences, 110: ( 2014 ) 658-668.

Nabi, G., Holden R. and Walmsley, A. (2006). "Graduate Career-Making and Business Start Up: A Literature Review", Education + Training, 48(5): 373-385.

Nwogwugwu, N., \& Irechukwu, G. N. (2015). Socio-Political Implications of Youth Unemployment on Nigeria's Economic Development, 6(4): 27-34.

Ofili, O. U. (2014). Challenges Facing Entrepreneurship in Nigeria. International Journal of Business and Management, 9(12). http://doi.org/10.5539/ijbm.v9n12p258.

Ogochukwu, (2016). Entrepreneurship Development and Unemployment Reduction in Nigeria. International Journal of Business and Management Review, 4(8): 27-43.

Osemeke, M. (2012). Entrepreneurial Development and Interventionist Agencies in Nigeria, 3(8): 255265. 
Osinubi \& A. O. Folawewo. (2006). "Monetary Policy and Macroeconomic Instability in Nigeria: A Rational Expectation Approach”. Journal of Social Science, 12(2): 93-100.

samsom, olubunmi and Olusegun. (2013). Investigation of Entrepreneurship as a Driver for Job Creation Among Youths.

Shapero, A. (1975). “The Displaced, Uncomfortable Entrepreneur”, Psychology Today, 9(6): 83-88.

Shapero, A. and Sokol, L. (1982). "The Social Dimensions of Entrepreneurship", Encyclopedia of Entrepreneurship, p. 72-90.

Shapero, A., \& Sokol, L. (1982). The Social Dimensions of Entrepreneurship. In C. Kent, D. Sexton \& K. H. Vespe (Eds.). The Encyclopedia of entrepreneurship (p. 72-90). Englewood Cliffs, NJ: Prentice-Hall.

Shepherd, H. \& Patzelt. (2017). Trailblazing in Entrepreneurship Creating New Paths for Understanding the Field. SBN 978-3-319-48701-4.

tende, s. b. a. (2014). Government Initiatives Toward Entrepreneurship Development in Nigeria. Global Journal of Business Research, 8(1).

Trading Economics. (2017). viewed October 28, 2017 extracted from https:/ko.tradingeconomics .com/nigeria/indicators

Turker, D. and Selcuk, S.S. (2009). "Which factors affect entrepreneurial intention of university students?", Journal of European Industrial Training, 33(2): 142-159. UNICEF 2000 Annual report available at https://unjobs.org/vacancies/1515686950601.

Wu, S., Wu, L. (2012). The impact of higher education on entrepreneurial intentions of university students in China. Journal of Small Business and Enterprise Development, 15(14): 752-774.

\section{Copyrights}

Copyright for this article is retained by the author(s), with first publication rights granted to the journal.

This is an open-access article distributed under the terms and conditions of the Creative Commons Attribution license (http://creativecommons.org/licenses/by/4.0/). 